\title{
MEMBANGUN PEMBERDAYAAN EKONOMI DI PESANTREN
}

\author{
Mohammad Nadzir ${ }^{1}$
}

\begin{abstract}
Abstrak
Pesantren sebagai bagian integral masyarakat mempunyai tanggung jawab untuk mengembangkan dan memberdayakan masyarakat dalam segala bidang termasuk dalam bidangan ekonomi. Hal ini merupakan tugas baru bagi pesantren yang sementara ini berkutat dalam bidang ilmu-ilmu keagamaan. Walaupun sifatnya masib sporadis, kurang terkoordinasi, tidak institusional dan belum disertai dengan visi dan misi yang jelas, serta perangkat pendukungnya. Peran ini memang tidak mudab bagi pesantren yang selama ini lebih berkonsentrasi pada bidang keagamaan dari pada bidang sosial kemasyarakatan, terutama dalam bidang ekonomi. Ini merupakan tantangan yang barus dihadapi oleh pesantren, untuk merubah pola dakwah yang menitikberatkean cara bil lisan menjadi pola dawah bil hal di tengah-tengah masyarakat yang semakin komplek.
\end{abstract}

Kata kunci : Pemberdayaan, ekonomi dan pesantren.

\section{Pendahuluan}

Studi-studi tentang pesantren selama ini sudah banyak dilakukan oleh para peneliti, namun sebagian besar mereka melihat pesantren dari dimensi, pendidikan sosial dan politik. Sedikit sekali yang melihat pesantren dari potensi ekonomi yang dimiliki oleh pesantren.

Pesantren di Indonesia yang jumlahnya mencapai ribuan sebenarnya mempunyai potensi yang sangat besar dalam bidang ekonomi. Namun potensi yang dimiliki oleh pesantren belum banyak diperhatikan, baik oleh pemerintah maupun pesantren sendiri. Pemerintah selama ini jarang melihat potensi ekonomi yang dimiliki oleh pesantren, karena pesantren dianggap lembaga pendidikan tradisional yang tidak mempunyai nilai strategis dalam bidang

\footnotetext{
${ }^{1}$ Dosen IAIN DPK Universitas Wahid Hasyim Semarang
} 
Membangun Pemberdayaan Ekonomi di Pessantren

ekonomi. Sedangkan sebagian besar pesantren menganggap bahwa persoalan ekonomi bukanlah urusan pesantren karena urusan ekonomi merupakan persoalan duniawi, sehingga tidak perlu diperhatikan secara serius.

Perspektif para pakar tentang pesantren secara mayoritas juga mengatakan demikian, bahwa pesantren merupakan lembaga tradisional yang bergerak dalam bidang pendidikan tradisional yang masih mempertahankan pembelajaran kitab-kitab klasik. Padahal jika kita melihat potensi dan perkembangan pesantren sekarang ini sebagaimana yang di katakan oleh Azyumardi Azra pesantren sekarang diharapkan tidak lagi sekedar memainkan fungsi tradisionalnya ${ }^{2}$ yaitu; "tranmissi dan transfer ilmu-ilmu Islam, pemeliharaan tradisi Islam, reproduksi ulama", tetapi juga menjadi pusat penyuluhan kesehatan, pusat pengembangan teknologi tepat guna bagi masyarakat pedesaan, pusat usaha-usaha penyelamatan dan pelestarian lingkungan hidup; dan lebih penting lagi menjadi pusat pemberdayaan ekonomi masyarakat dan sekitarnya. Maka dari itulah fungsi pesantren tidak hanya sebagai pusat pengkaderan pemikir-pemikir agama (center of exellence), sebagai lembaga yang mencetak sumber daya manusia (buman resource), tetapi juga diharapkan menjadi lembaga yang dapat melakukan pemberdayaan pada masyarakat (agent of development)..

Melihat fungsi yang dimilikinya sebenarnya pesantren dapat berperan sebagai lembaga perantara yang diharapkan dapat menjadi dinamisator dan katalisator pemberdayaan sumberdaya daya manusia, penggerak pembangunan di segala bidang, termasuk di bidang ekonomi ${ }^{3}$

Dengan kekuatan yang dimilikinya, pesantren mempunyai potensi untuk melakukan pemberdayaan umat terutama dalam bidang ekonomi. Karena melakukan pemberdayaan ekonomi merupakan bentuk dakwah bil hal dan sekaligus mengimplementasikan ilmu-ilmu yang dimilikinya secara kongkrit (aplikatiff). Di dalam Islam, ekonomi merupakan wasilah bukan maqashid, jadi ekonomi merupakan salah satu cara untuk mencapai kebahagiaan dunia dan akhirat. Hal ini tentunya sesuai dengan yang di ajarkan Islam bahwasanya harta dan kegiatan ekonomi merupakan amanah dari Allah SWT

2 Azyumardi Azra, Jaringan Ulama, Bandung, Mizan, 1997, hal. xxii

3 Amin Haidari, dkk., Masa Depan Pesantren dalam Tantangan Modernitas dan Tantangan Kompleksitas Global, IRD Press, Jakarta, 2004, hal: 193-194 
sebagai pemiliki mutlak terhadap segala sesuatu yang ada di muka bumi ini termasuk harta benda, pemilik hakiki kekayaan. ${ }^{4}$ Karena itulah orang yang beriman diperintahkan untuk meningkatkan dan menambah harta mereka melalui jalan yang sesuai dengan ajaran Islam, seperti dengan cara sedekah bukan dengan cara ribawi karena sedekah akan meningkatkan efek positif pada harta kekayaan. ${ }^{5}$

Konsep Islam tersebut seharusnya dijadikan dasar oleh pesantren untuk melakukan pemberdayaan ekonomi, membimbing dan mendampingi umat. Dengan demikian status harta secara de jure yang menjadi milik manusia mengakibatkan adanya hubungan antara manusia dan Allah memiliki beberapa implikasi. Dari sini sebenarnya pesantren mempunyai kekuatan yang bisa dimanfaatkan pesantren untuk melakukan pemberdayaan dalam ekonomi kerakyatan. Pesantren yang secara langsung bersentuhan dengan umat bisa menjadi media pemberdayaan masyarakat di bidang ekonomi.

\section{Pemberdayaan Ekonomi}

Terdapat banyak definisi pemberdayaan ekonomi ummat di banyak literatur yang dikemukakan oleh para ahli. Para ahli menggunakan kata "masyarakat" untuk menunjuk makna "ummat". Dari segi kebahasaan, pemberdayaan merupakan terjemahan dari empowerment, sedang memberdayakan adalah terjemahan dari empower. Menurut Oxford English Dictionary, kata empower memiliki dua arti, yaitu: (1). to give power atau autority to atau memberi kekuasaan, mengalihkan kekuatan atau mendelegasikan otoritas ke pihak lain; (2) to give ability to atau enable atau usaha untuk memberi kemampuan atau keperdayaan.

Sedangkan dari segi istilah (terminologi), banyak ahli yang menawarkan definisi pemberdayaan. Variasi definisi mengenai pemberdayaan bisa dijumpai di banyak literatur. Beberapa ahli memakai langsung memakai frase hal : 143

${ }^{4}$ Antonio, Muh. Syafi'i, Bank Syari'ah dari Teori ke Paraktek, Jakarta, Gema Insani, 2001,

${ }^{5}$ Al-Bahi, Manbaj al-Qur'an fi Tawtir al-Mujtama', Dar al-Fikr, Beirut 1974, hal :157

Volume VT/Edisi 1/Mei 2015 
Membangun Pemberdayaan Ekonomi di Pessantren

"pemberdayaan ekonomi" ketika menerangkan hal ini. Beberapa paragraf berikut adalah tokoh dan definisi pemberdayaan ekonomi yang dinyatakannya.

Hutomo menyatakan bahwa pemberdayaan ekonomi adalah penguatan pemilikan faktor-faktor produksi, penguatan penguasaan distribusi dan pemasaran, penguatan masyarakat untuk mendapatkan gaji/upah yang memadai, dan penguatan masyarakat untuk memperoleh informasi, pengetahuan dan ketrampilan, yang harus dilakukan dengan multiaspek, baik dari masyarakat sendiri, maupun aspek kebijakannya. ${ }^{6}$ Definisi di atas banyak dipakai oleh kalangan penyelenggara pemerintah.

Sumodiningrat menyatakan bahwa pemberdayaan ekonomi adalah usaha untuk menjadikan perekonomian yang kuat, besar, modern, dan berdaya saing tinggi dalam mekanisme pasar yang benar. Karena kendala pengembangan ekonomi rakyat adalah kendala struktural, maka pemberdayaan ekonomi rakyat harus dilakukan melalui perubahan struktural. ${ }^{7}$ Pemberdayaan ekonomi ummat adalah semua kegiatan yang bertujuan untuk meningkatkan kemampuan perekonomian ummat baik secara langsung (misalnya: pemberian modal usaha, pendidikan ketrampilan ekonomi, pemberian dana konsumsi), maupun secara tidak langsung (misalnya: pendidikan ketrampilan ekonomi, perlindungan dan dukungan terhadap kaum dengan kondisi ekonomi lemah, dan lain-lain). Beberapa literatur menyebutkan bahwa konsep pemberdayaan lahir sejak revolusi industri atau ada juga yang menyebutkan bahwa konsep pemberdayaan ada sejak lahirnya Eropa modern pada abad 18 atau renaisance, ketika banyak pihak mulai mempertanyakan determinasi gereja. Jika kemunculan ide pemberdayaan dipahami sebagai upaya untuk keluar atau melawan determinisme gereja serta monarki, maka pendapat yang menyakatan bahwa gerakan pemberdayaan mulai muncul pada abad pertengahan barangkali benar.

Di Eropa, wacana pemberdayaan muncul ketika industrialisasi menciptakan masyarakat penguasa faktor produksi dan masyarakat pekerja yang dikuasai. Pada saat itu, Karl Marx mendefinisikan pemberdayaan sebagai

${ }^{6}$ Mardi Yatmo Hutomo. Pemberdayaan Masyarakat dalam Bidang Ekonomi: Tinjauan Teoretik. dan Implementasi. Makalah Seminar Sehari Pemberdayaan Masyarakat yang diselenggarakan Bappenas, tanggal 06 Maret 2000 di Jakarta. Di akses dari www.bappenas.go.id. Dikutip pada 10 Januari 2011. hal: 6 . 
perjuangan kaum powerless untuk memperoleh surplus value sebagai hak normatif yang harus diterima masyarakat pekerja. Perjuangan untuk mendapatkan surplus value tersebut dilakukan melalui distribusi penguasaan faktor-faktor produksi. Dan perjuangan untuk mendistribusikan faktor-faktor produksi tersebut harus dilakukan melalui perjuangan politik. ${ }^{8}$

Di negara-negara berkembang termasuk di Indonesia, wacana pemberdayaan muncul ketika pembangunan yang dilaksanakan pemerintah menimbulkan disinteraksi sosial, kesenjangan ekonomi, degradasi sumber daya alam, dan alienasi masyarakat dari faktor-faktor produksi oleh penguasa. Penguasa memiliki akses yang lebih besar untuk menguasai kegiatan-kegiatan ekonomi yang akhirnya mempengaruhi banyak pihak dalam masyarakat. Halhal di atas akhirnya memunculkan dikotomi, yang membedakan antara masyarakat yang berkuasa dan masyarakat yang dikuasai. Untuk membebaskan masyarakat dari situasi ini, maka harus dilakukan pembebasan melalui proses pemberdayaan bagi yang dikuasai (empowerment of the powerless). Ini adalah alasan awal mengapa pemberdayaan dinilai penting untuk dilakukan.

Secara konseptual, pemberdayaan (empowerment), berasal dari kata "power" yang berarti "kekuasaan" atau "keberdayaan". Karenanya ide pemberdayaan bersentuhan dengan konsep mengenai kekuasaan. Kekuasaan seringkali dikaitkan dengan kemampuan yang dimiliki pihak pertama untuk membuat pihak ke-dua melakukan apa yang diinginkan pihak pertama, terlepas dari keinginan dan minat pihak ke-dua. ${ }^{9}$

Pemberdayaan menunjuk pada kemampuan orang atau kelompok, khususnya kelompok yang rentan dan lemah sehingga memiliki kekuatan atau kemampuan untuk: (a) memenuhi kebutuhan dasarnya sehingga memiliki kebebasan (freedom); (b) menjangkau sumber-sumber produktif yang memungkinkan kelompok lemah/rentan untuk meningkatkan pendapatannya, dan memperoleh barang dan jasa yang dibutuhkan; dan (c) berpartisipasi dalam pembangunan dan proses pengambilan keputusan-keputusan yang mempengaruhi kelompok lemah/rentan. ${ }^{10}$ Para ahli mengemukakan bahwa

\footnotetext{
${ }^{8}$ Ibid., hal: 3 .

9 Edi Suharto, Membangun Masyarakat, Memberdayakan Rakyat, Bandung: PT. Refika Aditama. 2005. hal: 57.

${ }^{10}$ Ibid., hal: 58 .
} 


\section{Membangun Pemberdayaan Ekonomi di Pessantren}

bahasan mengenai pemberdayaan hendaknya ditinjau dari tujuan, proses, dan cara-cara pemberdayaan yang dilakukan yang meliputi. ${ }^{11}$

a. Pemberdayaan bertujuan untuk meningkatkan kekuasaan pihak-pihak yang lemah atau kurang beruntung.

b. Pemberdayaan adalah sebuah proses yang dengannnya suatu pihak akan menjadi kuat untuk ikut berpartisipasi aktif dalam memperbaiki keadaan.

c. Pemberdayaan menunjuk pada usaha pengalokasian kembali kekuasaan melalui pengubahan struktur ekonomi yang ada di tengah masyarakat.

d. Pemberdayaan adalah suatu cara agar masyarakat, organisasi, dan komunitas mampu menguasai (berkuasa atas) kehidupannya.

Dengan demikian, pemberdayaan ekonomi adalah proses sekaligus tujuan. Sebagai proses, pemberdayaan ekonomi adalah serangkaian kegiatan untuk memperkuat kekuasaan atau keberdayaan kelompok lemah (kondisi ekonominya) dalam masyarakat. Sebagai tujuan, maka pemberdayaan menunjuk pada keadaan atau hasil yang ingin dicapai, dan konsep mengenai tujuan pemberdayaan ini seringkali digunakan sebagai indikator keberhasilan pemberdayaan sebagai sebuah proses. Bila konsep pemberdayaan di atas dilekatkan mendahului konsep ekonomi, maka didapati konsep baru yang lebih sempit dan spesifik. Pemberdayaan ekonomi merupakan kegiatan memberi kekuasaan pada pihak ke-dua (sasaran pemberdayaan) agar menjadi mampu dalam bidang ekonomi.

Konsep pemberdayaan ekonomi lahir sebagai antitesis terhadap model pembangunan dan model industrialisasi yang kurang memihak pada masyarakat mayoritas (yang bukan pemegang kekuasaan ekonomi). Konsep ini dibangun dari kerangka logika sebagai berikut: (1) bahwa pemusatan kekuasaan terbangun dari pusat penguatan faktor produksi; (2) pemusatan kekuasaan faktor produksi akan melahirkan masyarakat pekerja dan masyarakat penguasa pinggiran; (3) kekuasaan akan menghasilkan bangunan atas sistem pengetahuan, sistem politik, sistem hukum, dan ideologi yang manipulatif untuk memperkuat dan legitimasi, dan (4) kooptasi sistem pengetahuan, sistem

${ }^{11}$ Ibid., hal: 58-59. 
hukum, sistem politik, dan ideologi secara sistematik akan menciptakan dua kelompok masyarakat, yaitu: masyarakat berdaya dan masyarakat tunadaya. ${ }^{12}$

\section{Faktor-faktor yang Mempengaruhi Pemberdayaan Ekonomi di Pesantren}

1. Doktrin Keagamaan

Agama merupakan petunjuk bagi manusia, baik di dalam masalah keduniaan maupun masalah ibadah dengan Tuhan. Dalam segi muamalah (hubungan keduniawian) agama-agama samawi telah mengatur umatnya, baik yang berhubungan antar manusia dalam bidang pemerintahan, hukum, kemasyarakatan, maupun persoalan-persoalan yang berhubungan dengan ekonomi. Pada bidang ekonomi, para ilmuwan telah mengadakan suatu penelitian secara mendalam hubungan agama dan ekonomi, yang salah satu pokok penelitiannya adalah, adakah kontribusi agama terhadap semangat ekonomi pada masyarakat. Seperti yang dilakukan oleh Kenneth Boulding, di dalam penelitianya tentang pengaruh agama Kristen protestan terhadap semangat ekonomi, ia menemukan bahwa pengaruh agama protestan ternyata mempunyai dampak terhadap kehidupan ekonomi dan sejarah, bahkan lebih besar daripada pengaruh agama terhadap pemikiran ekonomi saja. Agama turut mempengaruhi pengambilan keputusan mengenai jenis komoditi yang diproduksi, terbentuknya kelembagaan ekonomi dan tentu juga praktek-praktek atau perilaku ekonomi. ${ }^{13}$

Pendapat di atas diperkuat oleh Tesis Max Weber yang membuktikan bahwa agama, dalam hal ini etik protestanisme, turut memberi saham terhadap perkembangan kapitalisme dan revolusi industri. ${ }^{14}$ Weber mengatakan bahwa Protestan berbeda dengan Katolik seperti yang diajukan oleh Aquino yang melihat kerja sebagai keharusan dam kelanjutan hidup. Maka Calvinisme yang merupakan salah satu paham dalam protestan,

\footnotetext{
12 Prajono, O.S dan Pranarka, A.M.W.. Pemberdayaan: Konsep, Kebijakan, dan Implementasi, Jakarta: Penerbit CSIS. 1996. hal: 269.

${ }^{13}$ Boulding, Keneth E., Beyon Economics, Essay On Society, Relegion ana Ethics, The University of Michigan, Ann Arbor, 1970: 180

${ }^{14}$ Lihat M. Dawam Raharjo, Etika Ekonomi Islam,Yogyakarta, Tiara Wacana, 1990, hal: 28
} 


\section{Membangun Pemberdayaan Ekonomi di Pessantren}

terutama sekte Puritanisme melihat kerja sebagai Beruf (panggilan). Kerja tidaklah sekedar pemenuhan keperluan tetapi merupakan tugas suci. Pensucian kerja (atau perlakuan terhadap kerja sebagai usaha keagamaan yang akan menjamin kepastian dalam diri akan keselamatan), berarti mengingkari sikap hidup keagamaan yang melarikan diri dari dunia. ${ }^{15}$

Sikap hidup keagamaan yang diinginkan oleh doktrin ini, kata Weber, ialah askese duniawi, yaitu intensifikasi pengabdian agama yang dijalankan dalam kegairahan kerja sebagai gambaran dan pernyataan dari manusia yang terpilih. Dalam kerangka pemikiran teologi seperti ini, maka semangat kapitalisme, yang bersandarkan kepada cita ketekunan, hemat, berperhitungan, rasional, dan sanggup menahan diri menemukan pasangannya. Sukses hidup yang dihasilkan oleh kerja keras bisa pula dianggap sebagai pembenaran bahwa ia, si pemeluk, adalah orang yang terpilih. ${ }^{16}$

Tesis Weber di atas membuktikan bahwa agama dalam hal ini etik protestanisme, turut memberi saham terhadap perkembangan kapitalisme dan revolusi industri, menarik perhatian luas. Seperti Tawney, Robert N. Bellah, berusaha mencari pola hubungan yang serupa antara agama Tokugawa dan kebangkitan Kapitalisme Jepang. Karl Max, dalam membahas berbagai aspek ekonomi, juga tidak lupa melihat agama, sebagai bangunan atas yang merupakan refleksi dari mode produksi. ${ }^{17}$

Gambaran di atas menunjukkan bahwa nilai-nilai etika agama mempunyai peranan yang kuat untuk menggerakkan semangat ekonomi seperti yang digambarakan Weber dalam bukunya The Protestan Ethic and the spirit of capitalism. Sekarang bagaimanakah dengan Islam. Di dalam Islam sebenarnya masalah perekonomian - yang masuk kategori urusan keduniaan (muamalah) - mempunyai bobot yang besar dalam agama, tidak hanya sekedar suplemen sebagaimana anggapan umum selama ini. Islam mengajarkan keseimbangan antara orientasi kehidupan dunia dan akhirat. Walau demikian, Islam yang mengajarkan etika kehidupan agar di dalam

15 Weber, Max, The Protestan Ethic and Spirit of Capitalism, diterjemahkan oleh Talcott Parsons, Newyork, Charles Scribner's Son, 1958. Hal : 58

16 Natsir, Nanat Fatah, Etos Kerja Wirausahawan Muslim, Gunung Jati Press, Bandung, 1999. Hal : 11-12

${ }^{17}$ M. Dawam Raharjo, op. cit, hal: 28 
memperoleh harta tetap menjaga perbuatan kebaikan terhadap orang atau menjaga hak-hak asasi orang lain; tidak serakah, tidak dengan merampas hak orang lain, tidak zalim, dan tidak merugikan orang lain. ${ }^{18}$

Islam memandang masalah ekonomi tidak dari sudut pandang kapitalis yang memberikan kebebasan serta hak kepemilikan kepada individu dan menggalakkan usaha secara perseorangan. Tidak pula dari sudut pandang komunis, yang ingin menghapuskan semua hak individu dan menjadikan mereka seperti budak ekonomi yang dikendalikan oleh negara. Tetapi Islam membenarkan sikap mementingkan diri sendiri tanpa membiarkannya merusak masyarakat 19

Untuk meningkatkan perekonomian Islam memberikan motivasi pada pemeluknya untuk bekerja keras dan mempunyai etos kerja yang tinggi. Karena Islam pada hakekatnya adalah agama yang mengajarkan dan menganjurkan umatnya untuk meraih kekayaan hidup baik secara material maupun spiritual. Anjuran tersebut paling tidak tercermin dalam dua dari lima rukun Islam yaitu zakat dan haji. Kedua pelaksanaan rukun Islam ini mensyaratkan adanya kekayaan atau kecukupan yang bersifat material. Jika pelaksanaan zakat dan ibadah haji memerlukan kecukupan material itu, lantas mencari materi menjadi wajib hukumnya. Dengan kata lain, rukun Islam mewajibkan umatnya untuk berkecukupan secara material. Nabi sendiri juga menegaskan bahwa al-yad al-ulya khairun min al-yad as-sufla, "tangan di atas lebih baik daripada tangan di bawah", atau memberi lebih baik daripada meminta 20

Al-Qur'an juga yang menjelaskan untuk bekerja keras dan mengajarkan pentingnya umat Islam untuk bekerja dan memikirkan ekonominya. Di antaranya QS. Al-Qashash [28]: 77: “Carilah pada apa yang telah dianugerahkan Allah kepadamu [kebahagiaan] negeri akbirat; dan janganlah kamu melupakan bagianmu dari [kenikmatan] duniawi. Berbuat baiklah [kepada

18 A. Qodri Azizy, Membangun Fondasi Ekonomi Umat, Meneropong Prospek Berkembangnya Ekonomi Islam, Yogyakarta, Pustaka Pelajar, 2004, hal. 25

19 Afzalur Rahman, Doktrin ekonomi Islam, Jilid I, Yogyakarta, Dana Bhakti Wakaf, 1995, hal : 10

${ }^{20}$ Musa Asy'arie, Etos Kerja Islam Sebagai Landasan Pengembangan jiwa Kewirausahaan, dalam Moh. Ali Aziz, dkk. (ed.), Pustaka Pesantren, tth., hal : 36

Volume VT/Edisi 1/Mei 2015 
Membangun Pemberdayaan Ekonomi di Pessantren

orang lain] sebagaimana Allah telah berbuat baik kepadamu. Janganlah kamu berbuat kerusakan di bumi”.

Dalam tafsir al-Jalalayn, ayat tersebut ditafsirkan; "Perolehlah [untuk] kepentingan akhirat [harta kekayaan] yang telah Allah berikan kepadamu, dengan cara menginfaqkan [sebagian] harta tersebut untuk ketaatan kepada Allah. Dan jangan kamu lupakan bagian kamu yang berkaitan dengan keduniaan untuk menjadi amal akhirat"21

Juga dalam QS. Al-Jumu'ah [62]: 10:

"Apabila telah ditunaikan shalat, maka bertebaranlah kamu sekalian di muka bumi dan carilah karunia Allah (yakni rizqi/harta) dan ingatlah kepada Allah banyak-banyak agar kamu beruntung".

Islam mendorong orang untuk bekerja. Hadits yang berbunyi: "Asyaddu an-nas 'adzabun yauma al-qiyamah al-maghfiy al-bathil (siksaan paling berat pada hari kiamat, adalah bagi orang yang hanya mau dicukupi orang lain dan hidup menganggur)".

Menurut Yusuf Qardhawi, Islam tidak menginginkan umatnya berada dalam kemiskinan. Karena akibat kemiskinan dan ketimpangan sosial bisa menyebabkan munculnya penyimpangan akidah ${ }^{22}$ Pendapat ini sesuai dengan sabda Rasulullah SAW :

"Kemiskinan dapat mengakibatkan kekafiran" (HR. Abu Na'im dari Anas).

Kemiskinan juga bisa menyebabkan orang tergelincir dalam akhlak dan moralitas yang tercela. Karena suara perut dapat mengalahkan suara nurani. Lilitan kesengsaraan pun bisa mengakibatkan seseorang meragukan nilai-nilai akhlak dan agama. ${ }^{23}$ Manusia sebagai subyek ekonomi, yang dalam kelompok besar disebut umat, oleh Islam dibebani (mukallaf) untuk berikhtiar sesuai dengan kadar potensinya. Taklif (pembebanan) ini berimplikasi pada banyak hal. Dalam disiplin fiqih -meskipun ekonomi sendiri bukan merupakan komponen fiqih- ikhtiar dalam arti luas disinggung karena erat kaitannya dengan usaha ekonomi. Kita mengenal

${ }^{21}$ Jalaluddin Muhammad ibn Ahmad Al-Mahaalli,dan Jalaluddn Muhammad ibn 'Abdurrahman ibn Abi Bakar, Tafsir Al-Jalilain, Semarang, Usaha Keluarga, tth, hal 326

${ }^{22}$ Yusuf Qardhawi, Daur al-Qiyam wa al-Akblaq fi al-iqtisad al-Islami, Maktabah Wahbah, Kairo, 1995, hal 24

${ }^{23}$ Ibid, hal. 25 
pasal-pasal muamalah sebagai modifikasi perekonomian secara lengkap dan terinci. $^{24}$ Berpangkal dari keberadaan manusia sebagai obyek ekonomi (produsen dan juga konsumen) maka kecuali upaya pembenahan sistem ekonomi, seperti peningkatan partisipasi modal swasta, hal yang tak kalah pentingnya adalah menggarap ketrampilan dan daya kemampuan pelaku ekonomi, yang berkaitan dengan usaha atau ikhtiar manusia. ${ }^{25}$

Menyinggung perihal ikhtiar dalam perekonomian, kita ingat sebuah hadits yang kurang lebih artinya, "Bekerja untuk memenubi kebutuhan ekonomi adalab wajib (fardhu) setelah kewajiban yang lain." Interpretasi hadits ini akan melahirkan kelompok-kelompok manusia produktif atau manusia yang bersumber daya tinggi yang sekaligus merupakan inti perekonomian. Barangkali dari kenyataan bahwa Allah tidak memberi rizqi dalam bentuk jadi dan siap digunakan, melainkan hanya dipersiapkan sebagai sarana dan sumber daya alam, maka sudah barang tentu untuk mengolahnya, mengikhtiari dalam bentuk industri, dan lain-lain.

Dari hadits ini, kita bisa menemukan pandangan yang proporsional terhadap ekonomi. Sikap ikhtiar dapat menghindarkan manusia dari sikap fatalistik (berserah pada nasib) yang secara tegas telah dilarang oleh Allah dalam surat Yusuf ayat 87:

"Janganlah kamu sekalian terputus asa atas rahmat Allah. Tiada yang berputus asa kecuali orang-orang kafir".

2. Santri dan Pemberdayaan Ekonomi

Konsep tentang peran santri dalam pemberdayaan ekonomi sangat menarik dibahas, karena santri yang setiap harinya disibukkan dengan berbagai aktivitas belajar atau mengaji, ternyata juga memiliki aktivitas ekonomi. Pada pesantren tertentu, santri memang dibekali dengan berbagai ketrampilan / keahlian di bidang ekonomi seperti koperasi, kerajinan dan berdagang. Semua itu dilakukan oleh pihak pesantren sebagai upaya untuk membekali para santri dengan berbagai skill keahlian atau setidaknya menyiapkan mental dan ketrampilan para santri supaya kelak ketika keluar dari pesantren sudah bisa mandiri. Oleh karena itu wajar jika pesantren

${ }^{24}$ Sahal Mahfudz, Nuansa Figh Sosial, Yogyakarta, LKiS, 1994, hal. 151

${ }^{25}$ Ibid., hal 150 


\section{Membangun Pemberdayaan Ekonomi di Pessantren}

berusaha mengembangkan diri dengan melakukan suatu tindakan nyata (dakwah bil hal) pada masyarakat di sekitar pesantren di segala bidang, termasuk di dalamnya pemberdayaan ekonomi.

Untuk melangkah pada Program pembangunan yang berbasis pemberdayaan ekonomi, paling tidak pesantren harus memenuhi persyaratan sebagai berikut: (a) kegiatan yang dilaksanakan harus terarah dan menguntungkan pesantren dan masyarakat sekitar terutama masyarakat yang lemah, (b) pelaksanaannya dilakukan oleh pesantren dan masyarakat sendiri, (c) karena pesantren dan masyarakat yang lemah sulit untuk bekerja sendiri-sendiri akibat kurang berdaya, maka upaya pemberdayaan ekonomi pesantren menyangkut pula pengembangan kegiatan usaha bersama (cooperatiff) dalam kelompok yang spesifik terkait dengan unit-unit usaha yang bisa diberdayakan kaum santri, (d) menggerakkan partisipasi masyarakat sekitar untuk saling membantu dalam rangka kesetiakawanan sosial. Dalam hal ini termasuk keikutsertaan orang-orang setempat yang telah maju.

Ada beberapa pesantren yang mencoba membuat satu ikhtiar menambah kemampuan santri di bidang wira usaha atau ekonomi. Berangkat dari kesadaran bahwa tidak semua santri akan menjadi ulama, maka beberapa pesantren mencoba membekali santri dengan ketrampilan di bidang pengembangan ekonomi. Artinya santri yang dihasilkan diharapkan mempunyai pengalaman dan syukur keahlian praktis tertentu yang nantinya dijadikan modal untuk mencari pendapatan hidup sekeluar dari pesantren. Kalau mencermati prilaku ekonomi di lingkungan pesantren pada umumnya, kita dapat menerka kemungkinan model apa yang sedang berjalan dalam usaha usaha tersebut. Setidaknya ada empat macam kemungkinan pola usaha ekonomi di lingkungan pesantren; Pertama, usaha ekonomi yang berpusat pada kyai sebagai orang yang paling bertanggungjawab dalam mengembangkan pesantren. Misalnya seorang kyai mempunyai perkebunan cengkih yang luas. Untuk pemeliharaan dan pemanenan, kyai mmelibatkan santri-santrinya untuk mengerjakannya. Maka terjadilah hubungan mutualisme saling menguntungkan: kyai dapat memproduksikan perkebunannya, santri mempunyai pendapat tambahan, dan ujungnya dengan keuntungan yang dihasilkan dari perkebunan cengkeh maka kyai dapat menghidupi kebutuhan pengembangan pesantrennya. 
seperti kasus di Pandeglang, yaitu pesantren Nurul Hidayah Cilaja kec. Pandeglang. ${ }^{26}$

Kedua, usaha ekonomi pesantren untuk memperkuat biaya operasional pesantren. Contohnya, pesantren memiliki unit usaha produktif seperti menyewakan gedung pertemuan, rumah dsb. Dari keuntungan usaha-usaha produktif ini pesantren mampu membiayai dirinya, sehingga seluruh biaya operasional pesantren dapat ditalangi oleh usaha ekonomi ini. Seperti pesantren Sidogiri yang mempunyai beberapa usaha seperti swalayan, toko-toko kelontong yang hasilnya untuk pembiayaan pesantren.

Ketiga, usaha ekonomi untuk santri dengan memberi ketrampilan dan kemampuan bagi santri agar kelak ketrampilan itu dapat dimanfaatkan selepas keluar dari pesantren. Pesantren membuat program pendidikan sedemikian rupa yang berkaitan dengan usaha ekonomi seperti pertanian dan peternakan. Tujuannya semata-mata untuk membekali santri agar mempunyai ketrampilan tambahan, dengan harapan menjadi bekal dan alat untuk mencari pendapatan hidup. Pesantren Baitul Hamdi di Menes Pandeglang dapat dijadikan sampel pesantren dalam jenis ini juga, karena disana santri diajak untuk bertani, dan berkebun. Keempat, usaha ekonomi bagi para alumni santri. Pengurus pesantren dengan melibatkan para alumni santri menggalang sebuah usaha tertentu dengan tujuan untuk menggagas suatu usaha produktif bagi individu alumni, syukur bagai nanti keuntungan selebihnya dapat digunakan untuk mengembangkan pesantren. Prioritas utama tetap untuk pemberdayaan para alumni santri. Hal ini seperti yang dilakukan oleh pesantren Sidogiri Pasuruan Jawa Timur dan pesantren Maslakul Huda di Kajen Pati Jawa Tengah.

Dalam melakukan pemberdayaan masyarakat, pesantren setidaknya memiliki tiga motif, Pertama, motif keagamaan, karena kemiskinan bertentangan dengan etika sosial ekonomi Islam. Kedua, motif sosial, karena kyai juga seorang pemimpin yang harus mengatasi krisis ekonomi setempat.

26 Ali Murtadlo, Pesantren dan Pemberdayaan ekonomi ((Studi Kasus Pesantren Baitul Hamdi dan Pesantren Turus di Pandeglang) Di akses dari www.bappenas.go.id. Dikutip pada 20 mei 2011. Hal : 6 


\section{Membangun Pemberdayaan Ekonomi di Pessantren}

Ketiga, motif politik, karena pemegang kekuasaan setempat mempunyai kepentingan-kepentingan pribadi pada tingkat mikro dan makro. Pondok pesantren dalam fungsinya melayani masyarakat, dapat pula dilihat dari upayanya dalam melayani masyarakat, terutama kebutuhan untuk menanggapi persoalan-persoalan kemiskinan, memberantas kebodohan, menciptakan kehidupan yang sehat dan sebagainya.). Di sinilah bisa ditunjukkan betapa pentingnya kehadiran pesantren yang tidak hanya mementingkan kepentingan sendiri tetapi juga kepentingan masyarakat sekitar lebih mendapat tempat dalam kerangka usaha meningkatkan kesejahteraan masyarakat baik lahir maupun batin. ${ }^{27}$

Hal ini penting untuk dipahami karena pesantren secara historis didirikan dari dan untuk masyarakat. Pesantren didirikan dengan tujuan mengadakan transformasi sosial bagi (masyarakat) daerah sekitarnya. Ia hadir mengabdikan dirinya mengembangkan dakwah Islam dalam pengertian luas, mengembangkan masyarakat sesuai dengan nilai-nilai keagamaan dan pada gilirannya didukung secara penuh oleh mereka. ${ }^{28}$

Aspek lain signifikansi pelibatan pesantren dalam pemberdayaan masyarakat, berpeluang pada kenyataan bahwa masyarakat Indonesia yang mayoritas terdiri dari komunitas muslim pada umumnya berada di daerah pedesaan. Pada sisi itu, pesantren yang memang berkembang dan tersebar di daerah-daerah pedesaan sampai derajat tertentu, merupakan representasi dari masyarakat muslim daerah-daerah pedesaan.

Kenyataan itulah yang membuat pesantren sampai saat ini masih berpengaruh pada hampir seluruh aspek kehidupan di kalangan masyarakat muslim pedesaan yang taat. Tetapi upaya untuk menuju ke arah pemberdayaan masyarakat melalui fungsi ekonomi pesantren terkadang dibenturkan dengan berbagai kenyataan yang bisa menjadi penghambat langkah tersebut. Salah satu contohnya adalah karena biasanya pesantren selalu menjadi tempat bagi keluarga dekat kiai, yang bisa berupa anak, cucu dan seterusnya atau biasa disebut dzurriyyah kiai. Mereka kadang bertumpu

${ }^{27}$ Achmad Zaini, Kiai Haji Abdul Wabid Hasyim His Contribution to Muslim Education, Yogyakarta, Titian Ilahi Press, 1998, hal: 126

28 Abd A’la, Pengembangan Metodologi pemahaman Keagamaan, Makalah disampaikan dalam Muktamar Pemikiran Islam di Lingkungan NU, Sukorejo, PBNU, 3-5 Oktober 2003, hal : 4 
secara ekonomis terhadap santri, apakah dalam bentuk penyediaan makanan, bahan kebutuhan sehari-hari, atau yang lainnya.

Di banyak pesantren selalu terdapat kios-kios kecil milik keluarga kiai yang terkadang menjadi tumpuan ekonomi keluarga. Inilah sulitnya ketika pesantren kemudian mencoba untuk memusatkan kegiatan ekonomi dalam satu lembaga. Kegagalan koperasi Pondok pesantren pada dasarnya adalah karena usaha itu dihadang oleh kepentingan-kepentingan internal. Selain itu harus diakui bahwa manajemen ekonomi pesantren juga relatif kurang baik, bukan dari aspek kejujurannya tapi administrasinya. ${ }^{29}$

Selain itu kekurangan juga kerap tumbuh pada persoalan yang bersifat paradigmatik. Satu contoh misalnya nilai-nilai kemandirian yang dianut pesantren masih lebih menampakkan aspeknya yang bersifat individual, atau sangat lokal dan belum menjadi sikap sosial kemasyarakatan yang transformatif. Persoalan itu ditambah dengan pemaknaan sebagian pesantren terhadap pengabdian dan pengembangan masyarakat yang masih terkesan parsial dan melulu ditekankan pada aspek pengembangan keilmuan keagamaan murni. Sebagai konsekuensi pemberdayaan masyarakat di kalangan pesantren belum disentuh secara kreatif dan serius dalam bentuk penyatuan yang integral dan eksplisit ke dalam kurikulum yang dikembangkan pesantren. Tradisi itu tidak cukup dalam dirinya sendiri untuk memetamorfosis sebagai nilai civil society yang berkeadaban, universal dan berorientasi jauh ke depan. ${ }^{30}$

Untuk menambal kekurangan tersebut, maka yang harus diperhatikan dalam penguatan kelembagaan itu antara lain adalah, pertama, menganalisis kebutuhan subjek sasaran ekonomi atau yang disebut sebagai need-assessment. Analisis kebutuhan diperlukan agar apa yang akan dipasarkan itu memang menjadi kebutuhan sasaran. Pada tahap awal tentunya harus dibidik kebuthan-kebutuhan santri dan masyarakat sekitar, agar produk yang ditawarkan akan segera diperoleh nilai imbal balik. Baru bisa bergerak ke sektor yang lain, jika kondisi memang sudah memungkinkan. Kedua, melakukan analisis potensi SDM untuk kegiatan (ekonomi) tersebut. Pelajar, 2003, Hal : 38

29 Usman, Sunyoto, Pembangunan dan Pemberdayaan Masyarakat, Yogyakarta: Pustaka ${ }^{30}$ Ibid., hal: 39 


\section{Membangun Pemberdayaan Ekonomi di Pessantren}

Apakah sudah ada SDM yang bisa dan mampu untuk menjadi agen bagi pengembangan kelembagaan ekonomi pesantren tersebut? Pesantren sesungguhnya kaya dengan SDM yang berkualitas, hanya saja belum disentuh dengan kekuatan maksimal untuk itu. Ketiga, memetakan kebutuhan dan potensi untuk dijadikan sebagai rancangan program yang memadai. Keempat, melaksanakan program dengan memperhatikan jaringan kerja atau networking yang telah dimiliki oleh pesantren. Kelima, melakukan evaluasi kinerja apakah sudah ada kemajuan atau belum.

Strategi tersebut sebenarnya bisa diwujudkan dalam berbagai ranah. Karena pesantren pada umumnya berada di daerah pedesaan, maka strategi yang tepat untuk melakukan pemberdayaan masyarakat haruslah tidak jauh dari bidang tersebut. Sunyoto Usman memberikan beberapa alternatif wilayah yang bisa menjadi wilayah garapan pesantren dalam rangka pemberdayaan masyarakat. ${ }^{31}$

Berdasarkan hal tersebut dikembangkan beberapa pendekatan yang memungkinkan bisa diterapkan dalam kegiatan pemberdayaan ekonomi, yaitu (1) upaya pemberdayaan ekonomi pesantren harus terarah kepada pesantren yang benar-benar membutuhkan dan masyarakat di sekitarnya banyak yang miskin atau lemah, (2) pendekatan kelompok unit usaha untuk memudahkan pemecahan masalah yang dihadapi bersama-sama, (3) pendampingan kepada mereka selama proses pemberdayaan yang dilakukan dengan pembentukan kelompok yang dilakukan oleh pendamping yang sifatnya lokal, teknis dan khusus.

Karena sebenarnya pendidikan wirausaha bukanlah sesuatu yang asing dalam pesantren. Terutama tentang konsekuensi dari pendidikan semacam itu yaitu etos kerja keras. Hal semacam itu selalu menjadi tekanan pokok dalam pendidikan di pesantren. Akan tetapi pendidikan kepengusahaan (wirausaha) tersebut tidak terkoordinir dan tidak direncanakan dan untuk itu mestinya harus dibuat kerangkanya. Akibatnya akan keluar usahawan-usahawan yang mencari-cari jalan sendiri. Mereka akan menjadi usahawan-usahawan yang otodidak, yang tidak mendekati masalahnya dari segi-segi ilmiah tetapi berdasarkan intuisi. Dan akhir-akhir ini juga ada upaya memasukkan pendidikan keterampilan ke dalam

${ }^{31}$ Ibid., Hal : 40 
pesantren. Usaha semacam itu adalah usaha yang terpuji dan bukanlah suatu yang buruk dalam dirinya. ${ }^{32}$

Dalam diri santri sudah mulai ditanamkan kesadaran dan keinginan mengubah kehidupan masyarakat melalui penciptaan lapangan kerja berdasarkan suatu pandangan agama, baik di bidang pertanian, kelautan, produksi, pasar modal, koperasi maupun usaha kecil. Namun harus ada kerangka yang jelas yang mendukung ke arah sana, setidaknya ada konsep yang jelas sehingga bisa diukur letak keberhasilan dan kegagalannya. Kerangka itulah yang diharapkan bisa menumbuhkan sikap jiwanya. Walaupun secara jujur wacana diskursus ekonomi, termasuk bisnis, dan sejenisnya, tidak pernah menjadi topik dalam pengajian atau bahkan dalam dakwah. Dan masih banyak lagi perilaku para muballigh dan pemikir Islam yang pada intinya menyudutkan dan meremehkan aktifitas ekonomi. Oleh karena itu, wajar kalau kini umat Islam secara keseluruhan lebih miskin dan terbelakang ketimbang non-muslim. Umat Islam pada umumnya pemalas dan pendidikan mereka umumnya masih rendah. Kenyataan keterbelakangan, kemalasan, kebodohan dan kemiskinan di mayoritas umat Islam adalah hasil dan produk pemahaman dan pemaknaan ajaran Islam dan sekaligus prakteknya. Ini yang harus direformasi atau bahkan perlu ada upaya radikal dan mendasar (revolusi) untuk memahami Islam dan sekaligus mengamalkannya.

Seharusnya, ajaran ideal Islam itulah yang dijadikan tolak ukur kehidupan umatnya. Untuk membicarakan Islam realita yang lebih terurai, Azizi ${ }^{33}$ mengemukakan tiga hal; (1) salah paham yang berarti menjadikan salah pengamalan ajaran atau perbuatan yang keliru (tidak sesuai dengan ajaran Islam); (2) salah penggunaan dalil, yang seharusnya tidak dipakai; dan (3) ajaran yang tidak/kurang dikembangkan oleh para pemikirnya. Keduanya ini sangat berpengaruh negatif terhadap keberadaan ekonomi umat Islam.

32 Abdurrahman Wahid, Prisma Pemikiran Gus Dur, Yogyakarta, LKiS, 1999, Hal : 114

${ }^{33}$ A. Qodri Azizy, op.cit., hal :33 


\section{Kesimpulan}

Pesantren sebagai lembaga yang hidup di tengah-tengah masyarakat mempunyai peran yang sangat penting, baik yang terkait dengan persoalan keagamaan (moral force) maupun yang terkait dengan sosial kemasyarakatan. Untuk melakukan hal tersebut ada beberapa hal yang dapat dilakukan oleh pesantren.

1. Mempersiapkan para santri dengan memberikan bekal keahlian-keahlian tertentu, seperti pertanian, cara berdagang, bengkel dan lain sebagainya sehingga ketika mereka keluar dari pesantren mempunyai bekal untuk bekerja.

2. Menanamkan jiwa wira usaha pada santri, dengan memberikan wawasan kepada mereka sejak dini bahwa bekerja merupakan perintah agama. Karena mencari nafkah untuk menghidupi diri sendiri dan keluarga merupakan bagian yang tak terpisah dari ajaran Agama.

3. Perlu adanya pemahaman dari kalangan pesantren bahwa persoalan sosial di masyarakat seperti kemiskinan, ketidak adilan, juga merupakan tanggung jawab pesantren sebagai bagian dari hablum min al anas dan dakwah bil hal. 


\section{DAFTAR PUSTAKA}

Abdurrahman Wahid, Prisma Pemikiran Gus Dur, Yogyakarta, LKiS, 1999.

Azyumardi Azra, Jaringan Ulama, Bandung, Mizan, 1997

Amin Haidari, dkk., Masa Depan Pesantren dalam Tantangan Modernitas dan Tantangan Kompleksitas Global, IRD Press, Jakarta, 2004

Antonio, Muh. Syafi'i, Bank Syari'ah dari Teori ke Paraktek, Jakarta, Gema Insani, 2001

Al-Bahi, Manhaj al-Qur'an fi Tawtir al-Mujtama', Dar al-Fikr, Beirut 1974

Achmad Zaini, Kiai Haji Abdul Wabid Hasyim His Contribution to Muslim Education, Yogyakarta, Titian Ilahi Press, 1998.

Boulding, Keneth E., Beyon Economics, Essay On Society, Relegion ana Ethics, The University of Michigan, Ann Arbor, 1970

Jalaluddin Muhammad ibn Ahmad Al-Mahaalli,dan Jalaluddn Muhammad ibn 'Abdurrahman ibn Abi Bakar, Tafsir Al-jalilain, Semarang, Usaha Keluarga, th,.

Mardi Yatmo Hutomo. Pemberdayaan Masyarakat dalam Bidang Ekonomi: Tinjauan Teoretik dan Implementasi. Makalah Seminar Sehari Pemberdayaan Masyarakat yang diselenggarakan Bappenas, tanggal 06 Maret 2000 di Jakarta. Di akses dari www.bappenas.go.id. Dikutip pada 10 Agustus 2008.

Prajono, O.S dan Pranarka, A.M.W.. Pemberdayaan: Konsep, Kebijakan, dan Implementasi, Jakarta: Penerbit CSIS. 1996

M. Dawam Raharjo, Etika Ekonomi Islam, Yogyakarta, Tiara Wacana, 1990

Weber, Max, The Protestan Ethic and Spirit of Capitalism, diterjemahkan oleh Talcott Parsons, Newyork, Charles Scribner's Son, 1958

Natsir, Nanat Fatah, Etos Kerja Wirausahawan Muslim, Gunung Jati Press, Bandung, 1999.

Musa Asy'arie, Etos Kerja Islam Sebagai Landasan Pengembangan jiwa Kewirausahaan, dalam Moh. Ali Aziz, dkk. (ed.), Pustaka Pesantren, tth.

Yusuf Qardhawi, Daur al-Qiyam wa al-Akhlaq fi al-iqtisad al-Islami, Maktabah Wahbah, Kairo, 1995, hal 24

SahalMahfudz, Nuansa Figh Sosial, Yogyakarta, LKiS, 1994.

Volume VT/Edisi 1/Mei 2015 
Membangun Pemberdayaan Ekonomi di Pessantren

(Balitbang kemenag go.id).

Usman, Sunyoto, Pembangunan dan Pemberdayaan Masyarakat, Yogyakarta: Pustaka Pelajar, 2003. 